\title{
USING COOPERATIVE LANGUAGE LEARNING IN IMPROVING THE STUDENTS' PRONUNCIATION ACCURACY AND FLUENCY
}

\author{
Muhammad Rochman \\ ABA Balikpapan \\ muhroc@gmail.com
}

\begin{abstract}
This research aimed to find the improvement of the students' Pronunciation Accuracy and Fluency by using Cooperative Language Learning at Akademi Bahasa Asing Balikpapan at Third Semester Students in Balikpapan East Kalimantan in the 2018/2019 Academic Year. Cooperative Language Learning was used in a Classroom Action Research (CAR). The research had been conducted in two cycles, each cycle consist of four meetings. It employed Pronunciation test as instrument. A number of research subjects were 37 students in third semester. The instruments were test and observation. The research findings showed that Cooperative Language Learning could improve the students' Pronunciation mastery from cycle I to cycle II. The students' achievement from D-Test to cycle I was $12.50 \%$, and after finishing cycle II the students' achievement became $16.27 \%$. Based on the research findings, the researcher concludes that Cooperative Language Learning gave a significant contribution in learning process of Pronunciation accuracy and fluency.
\end{abstract}

Keywords: Pronunciation, Cooperative Language Learning, Fluency and accuracy

CPendidikan Bahasa Inggris FPISH IKIP BU Malang

\section{Introduction}

Problems in teaching and learning English as a Foreign Language (TEFL) relates to both lecturers and learners. A distinction is commonly made between foreign language (LF) learning and second language (L2) learning. In foreign language (LF) learning the target language is studied in a school setting in a classroom. In second language (L2) learning the new language is initially learned without the aid of formal instruction, through exposure in a natural setting (Keeves \& Darmawan, 2017)

This problem is partly affected by teaching methods. To date, a focus on student-centered learning may well be the most important contribution of constructivism. Therefore, discusses constructivism learning theory as a paradigm for teaching and learning. Constructivism is a learning theory found in psychology which explains how people might acquire knowledge and learn. It therefore has direct application to education. The theory suggests that humans construct knowledge and meaning from their experiences (Olusegun, 2015).

The teaching cooperative learning method refers to a systematic instructional method in which students work together in small groups to accomplish shared learning goals. The data in a large amount of research shows, compared with competitive and individualistic efforts, cooperation has positive effects on a wider range of outcomes (Zhang, 2010).

There is no doubt that Cooperative Learning can be used as an effective approach to encourage students to work together as one team inside the class (Mahmoud, 2018). He stated that In fact, the spirit of competitiveness and the domination of individualism may be reduced and lessened through adopting the approach of cooperative learning that provides a supportive learning environment for students in which they can acquire and exchange ideas, 
information and knowledge. In writing class, small groups can be used to create communication, interpersonal and team skills as members of each group do not have the same background or ability in EFL writing. This sort of variety helps students within each group support their peers as they can complement each other's strengths and weaknesses in EFL writing; some of them may have strong background in vocabulary or grammar while other students may have good background about the topic they are discussing. Following this way, low level students can benefit from their strong-level peers' feedback with regard to their grammatical, vocabulary, punctuation and spelling mistakes, and at the same time good students will feel satisfied and proud that they had a significant role in helping their low level classmates (Mahmoud, 2018).

Lecturers often provide insufficient opportunities for learners to practice English. To make the situation worse, both lecturers and learners frequently use Indonesian language throughout English classes. As according to Saricca (2018) all students are different and each have their own way of processing how they learn something new. The two main teaching and learning methods in our world today are active learning and traditional lecture. Both these methods are significant in their own way. There is something more people can do to educate students with enthusiasm and interest, rather than students dreading to sit through another lecture. Instead of old time lectures where only the lecturer speaks and students listen. Active learning is student-centered, an open setting where students can feel the freedom to express what they know and what they want to know more about, and active learning revolves more on listening to the student, not having the student just listen. Lecturers should take the initiative to give students the opportunity of full communication and voice in the classroom.

Active learning approaches also often embrace the use of cooperative learning groups, a constructivist-based practice that places particular emphasis on the contribution that social interaction can make (Brame, 2015). The active learning is necessarily use to teaching language learning, especially English. English as a foreign language (EFL) in Indonesia is different to English as second language in most common wealth countries. As it also stated by Nguyen and Terry (2017) that language learning strategies, particularly within the tertiary environment, have moved beyond rote learning, grammar exercises and primary and high school approaches to language development. The current strategies and processes of language learning at the tertiary level are also dependent on many factors such as individual aptitude, perseverance, hard work, and the teacher and student's positive attitudes.

According to Gillies (2016), cooperative learning is widely recognized as a pedagogical practice that promotes socialization and learning among students from pre-school through to tertiary level and across different subject domains. It involves students working together to achieve common goals or complete group tasks - goals and tasks that they would be unable to complete by themselves.

The statement is also supported by Herrman (2010) that cooperation exists when individuals work together in a group in order to promote both their individual learning outcomes as well as the learning outcomes of their peers. According to this theory, cooperation is most effective when students perceive that they share similar goals and when the individual members' goals are positively dependent on the actions of the group. Such positive interdependence 
is assumed to enhance promotive interaction, that is, students encouraging and helping each other to reach their goals, students giving each other feedback, students challenging each other's' conclusions and reasoning, and students taking the perspectives of others to better explore different points of view. Promotive interaction, in turn, is expected to lead to higher academic achievement.

\section{Research Method}

The method that is used in this research was a Classroom Action Research (CAR). It was conducted through two cycles to observe the students' improvement in Pronunciation English through Cooperative Language Learning. This part covers research location, research time and research cycle, as follows: This research will take place at Akademi Bahasa Asing Balikpapan at North Balikpapan District, East Kalimantan especially the second semester in 2018/2019 academic years. The research will do at early of April until the end of December, 2018. The research is conducted through two cycles. Each cycle consisted of four steps; they were planning, action, observation and reflection. The aim of this point was observing the students' improvement in Pronunciation by using Cooperative Language Learning.

Research variables and indicators used in this research were two variables, they were: Independent Variable; which is the independent variable is the use of Cooperative Language Learning to improve the students' Pronunciation mastery. It is an approach that was used by the lecturer at the classroom during teaching and learning process. The second variable is Dependent Variable; which is the dependent variable consisting of accuracy and fluency in Pronunciation mastery with the indicators as follows: a. the indicators of accuracy: pronunciation and vocabulary; and $b$. the indicator of fluency: self confidence.

Research Instruments was implemented first methods of Tests will use to asses and examine the students' Pronunciation mastery. The researcher will give tests in each cycle to find out the improvement of the students' Pronunciation mastery and effectiveness of using Task -Based Approach to improve the students' Pronunciation mastery. The second method was Observation sheet will use to collect data about the students' participation in teaching learning process in Pronunciation and implementing Cooperative Language Learning.

The subject of the study taught the third semester students of Akademi Bahasa Balikpapan, East Kalimantan especially the 2018/2019 academic year. The students consist of 37 students. The technique of data collection uses in this research is as follow: firstly; Pronunciation test will use at the end of every cycle by using criteria of Pronunciation test to measure students' Pronunciation improvement. Secondly; Observation would be used to measure the students' participation during the teaching and learning process by using Cooperative Language Learning.

\section{Result and Discussion}

In this section, the researcher describes the result of data analysis based on the problem statement. The result of data analysis indicates that there is an improvement of the students' Pronunciation mastery through Cooperative Language Learning Approach at the third semester of Akademi Bahasa Asing Balikpapan Balikpapan, East Kalimantan. The students' improvement could be seen clearly in the following explanation: 
The Improvement of the Students' Pronunciation Accuracy

The improvement of the students' Pronunciation accuracy, which focused on pronunciation and vocabulary as indicators at the first year students of Akademi Bahasa Balikpapan, East
Kalimantan as result of the students' assessment of cycle I and cycle II are described as follows:

\begin{tabular}{|l|l|l|l|l|l|l|l|}
\hline \multirow{3}{*}{ Indicators } & \multicolumn{4}{l}{ Scores (\%) } & \multicolumn{4}{l|}{ Improvement (\%) } \\
\cline { 2 - 8 } & D-test & Cycle I & Cycle II & D & CI & DT \\
& & & & T & C I & CII & C II \\
\hline Pronunciation & 42.18 & 54.64 & 69.94 & 12.46 & 15.3 & 27.76 \\
\hline Vocabulary & 39.91 & 53.62 & 71.27 & 13.71 & 17.65 & 31.36 \\
\hline$\sum \mathrm{x}$ & 82.09 & 108.26 & 141.21 & 26.17 & 32.95 & 59.12 \\
\hline
\end{tabular}

Table 1: The Improvement of the Students' Pronunciation Accuracy

The table above shows that the Cooperative Language Learning improves the Pronunciation accuracy of the students from D-test to cycle I and cycle II In which cycle II is greater than cycle I and D -test. About the mean score of Pronunciation accuracy in cycle II, the students get 70.60, greater than cycle I and D -test where the students get 54.13 or fair and the students get 41.04 in D-test of Pronunciation accuracy. It indicates that the improvement of the students' Pronunciation accuracy is 13.09 in D-test to cycle 1, the improvement in cycle 1 to cycle II is 16.47, and the improvement in D -test to cycle II is 29.56. It indicates that Cooperative Language Learning method improves students' Pronunciation mastery significantly.

To see clearly the improvement of the students' Pronunciation accuracy, the

The chart above shows the improvement of the students' Pronunciation accuracy. In cycle II is

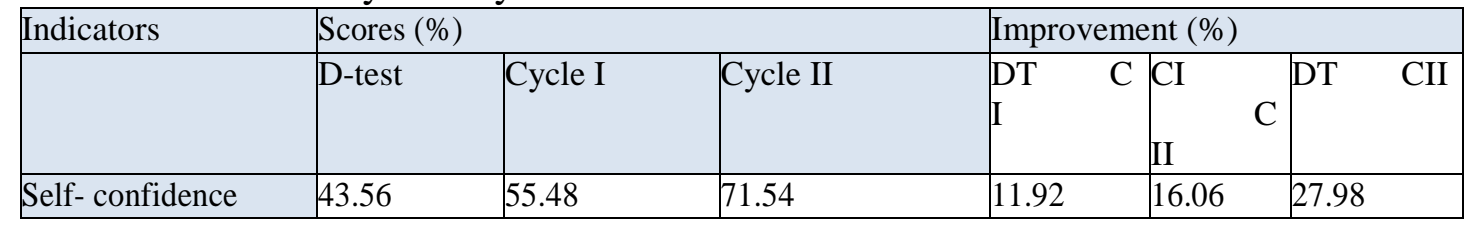

higher 6.4 than cycle I is 4.8 and D-Test is 3.4. It also shows that the result of D Test is the lowest achievement. After evaluation in cycle I and cycle II, there is a significant improvement of the students' Pronunciation accuracy that shown clearly in the chart after taking an action in cycle through Cooperative Language Learning.

\section{The Improvement of the Students' Pronunciation Fluency}

The application of Cooperative Language Learning in improving the students' Pronunciation fluency deals with self-confidence as indicator at the third semester students of Akademi Bahasa Balikpapan, East Kalimantan. As result of the students' assessment of cycle I and cycle II is described as follows: 
The table above shows that the Cooperative Language Learning also improves the Pronunciation fluency of the students from D-test to cycle I and cycle II, in which cycle II is greater than cycle I and D -test. About the mean score of Pronunciation fluency in cycle II, the students get 71.54, greater than cycle I and D -test where the students get 55.48 and the students get 43.56 in Dtest of Pronunciation fluency. It indicates that the improvement of the students' Pronunciation fluency is 11.92 in D-test to cycle I, the improvement in cycle I to cycle II is 16.06 , and the improvement in the D -test to the cycle II is 27 . 98. It also indicates that the students' Pronunciation mastery improved significantly through the use of Cooperative Language Learning.

To see clearly the improvement of the students' Pronunciation fluency, the researcher presents the chart 2.
The chart above shows the improvement of the students' Pronunciation fluency in cycle II is higher 71.54 than cycle I is 55.48 and DTest is 43.56. It also shows that the result of D -Test is the lowest achievement. After evaluation in cycle I and cycle II, there is a significant improvement of the students' Pronunciation accuracy that shown clearly in the chart after taking an action in cycle through Cooperative Language Learning.

The Improvement of Students' Pronunciation Mastery

The improvement of students' Pronunciation mastery through the use of Task -based Approach is dealing with Pronunciation accuracy and Pronunciation fluency. The improvement of the students' Pronunciation mastery that covers accuracy and fluency can be seen clearly in the following table 3 .

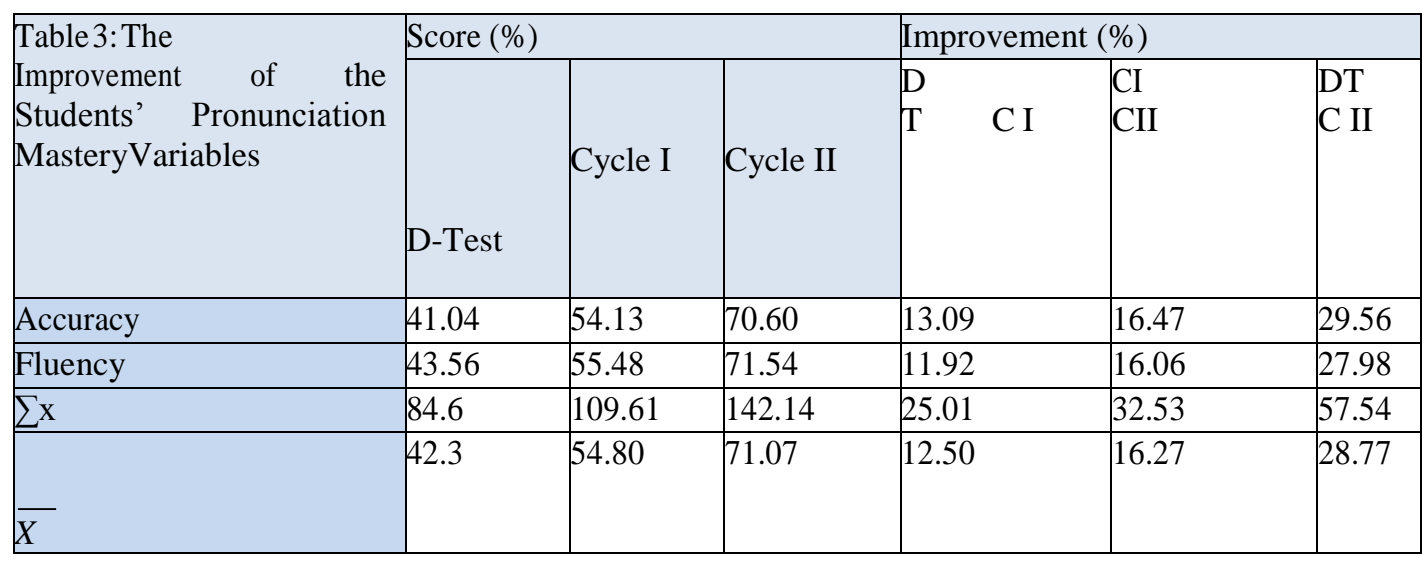

D-test. It indicates that the improvement of the students' Pronunciation mastery is

The table above shows that the students' Pronunciation mastery improves from D -test to cycle I and cycle II. In which cycle II is greater than Cycle I and the D -test. The mean score of Pronunciation mastery in the cycle II, the students get 71.07 or good greater than cycle I, the students get 54.80 or fair and the students get 42.3 or poor in
12.50 in D-test to cycle $\mathrm{I}$, the improvement from cycle I to cycle II is 16.27, and the improvement from D -test to cycle II is 28.77 . It indicates that the students' Pronunciation mastery improved significantly through the use of Task -based Approach.

To see clearly the improvement of the students' Pronunciation mastery, the 
researcher presents in the following chart 3.

The chart above shows that the students' Pronunciation mastery improves from D-test to cycle I and cycle II. In which cycle II is the highest of all. Then, cycle II is higher than cycle II. The mean score of Pronunciation $\mathrm{s}$ kill in cycle II is 71.07. Then, the mean score of the students in cycle I is 54.80 and the students get 42.30 in D-test.

3. The Improvement of Students' Activeness in the Process of Teaching and Learning.

The result of observation of the students' activeness in teaching and

\begin{tabular}{|ll|l|l|l|}
\hline Cycles & Meetings & Percentages & Averages & Improvement \\
\hline I & I & $42.42 \%$ & $52.70 \%$ & \\
& II & $51.38 \%$ & & \\
& III & $57.57 \%$ & & \\
& IV & $59.45 \%$ & $7.35 \%$ \\
\hline II & I & $73.38 \%$ & $75.05 \%$ & \\
& II & $72.79 \%$ & & \\
& III & $74.32 \%$ & & \\
\hline & IV & $79.72 \%$ & & \\
\hline
\end{tabular}

The table above shows that the average of the students' activeness in teaching and learning process in each cycle through observation sheet by observer. The percentages of the cycle I from the first meeting $\mathrm{t} o$ the fourth meeting are $42.42 \%, 51.38 \%, 57.57 \%$, and $59.45 \%$. Moreover, the percentage of the cycle II from the first meeting to the fourth meeting are $73.38 \%, 72.79 \%$, $74.32 \%$, and $79.72 \%$. In addition, the average score in every cycle, in cycle $\mathrm{I}$ is $52.70 \%$ and in cycle II is $75.05 \%$.

As the result, the improvement of the students' activity is $22.35 \%$.

The students' observation in learning Pronunciation by Using Cooperative Language Learning at the Third semester students of Akademi Bahasa Asing Balikpapan, East Kalimantan in class. In chart above, presents the students' situation during teaching learning process in learning process toward of the application of Cooperative Language Learning in improving the students' Pronunciation mastery at the third semester students of Akademi Bahasa Asing Balikpapan, East Kalimantan in class which is conducted in 2 cycles during 8 meetings is taken by the observer through observation sheet. It can be seen clearly through the following table:

Table 4: The Observation Result of the Students' Activeness in Teaching and Learning Process.
Pronunciation from cycle I to the cycle II. From the chart, it's known that there is changing of students' situation of learning Pronunciation from cycle I to cycle II. The student s' participation in learning Pronunciation within the mean score is $52.70 \%$ and change to be $75.05 \%$. As it can be seen that the improvement of the students' activity from cycle I to cycle II is $22.35 \%$.

\section{Conclusion}

The use of Cooperative Language Learning can increase the students' Pronunciation accuracy. This lead the conclusion that implementation of this approach is much needed in English language teaching and learning especially in Pronunciation. The students' score in the cycle I is 55.02 and it gets improve after cycle II, it is 70.60 .

Cooperative Language Learning can improve the students' Pronunciation 
fluency in which the improvement is dealing with self confidence. They are excited to the given topics because the topics deals with the real -life conversation, so it's easy for them to make conversations and present them in front of the classroom with their own group. The students' average score of fluency in cycle I is 55.48 but in cycle II is 71.54 .

Cooperative Language Learning motivates the students in teaching and learning process. The students' participation in learning Pronunciation within the mean score is $52.70 \%$ in Cycle I and change to be $75.05 \%$ in Cycle II. Based on the research findings, the researcher concludes that Cooperative Language Learning gave a significant contribution in learning process of Pronunciation accuracy and fluency

\section{References}

Brame, C. 2015. Active Learning. The National Survey of Student Engagement (NSSE) and the Australasian Survey of Student Engagement (AUSSE) by Cynthia J. Brame, PhD, CFT Assistant Director.

Bryne, D. 1998. Teaching Oral English. New York: Longman.

Dalton, E. 1998. Teaching Longman Group Ltd.

Doud, H. 2009. The Cooperative Language Learning to Improve Students' Pronunciation Mastery. Lebanese American University. Edward, C \& Willis, J. 2005. Lecturer Exploring Tasks in English Teaching. London: Palgrave Macmillan.

Gay, L.R. 1981. Educational Research

Competence for Anayisis and Applications, 2 nd Edition. Charles E. Meril Publishing Company Columbus.
Genc, B., \& Bada, E. 2005. Culture in Language Learning and Teaching . The Reading Matrix. Vol. 5, No. 1.

Gillies, R. (2016). Cooperative Learning: Review of Research and Practice. Australian Journal of Teacher Education. Vol 41, 3, March 2016. The University of Queensland

Guitterez, D. 2005. Developing Oral Mastery through Communicative and Interactive Tasks.http://www.scielo.org.co/ scielo.php?script=sci_arttext\& pid=S1657.

Harmer, J. 2000. The Practice of English language Teaching. London: Lo ngman Group Ltd.

Herrman, K. (2010). The impact of cooperative learning on student engagement: Results from an intervention. Active Learning in Higher Education 14(3) 175-187 (C) The Author(s) 2013 Reprints and permissions: sagepub.co.uk/journalsPermissio ns.nav DOI: $10.1177 / 1469787413498035$ alh.sagepub.com.

Hiebert, H. E. and Kamil, L. M. 2005. Teaching and Learning Vocabulary: Bringing Research to Practice . London: Lawrence Erlbaum Associates.

Hornby, A.S. 1995. Oxford Advanced Learners Dictionary. Oxford: Oxford University Press. http:// www.yde.yildiz.edu.tr/ uddo/ belgeler/ inca -FundaHatipTBL.htm.

Keeves, J.P and Darmawan, I.G.N. 2017. Issues in language learning. International Education Journal, 2007, 8(2), 16-26. ISSN 14431475 (C) 2007 Shannon Research Press. http://iej.com.au

Larsen-Freeman, Diane. 2000. Technique and Principles in 
Language Teaching. Oxford: Oxford University Press.

Lin, Z. 2009. Task based approach in foreign language teaching in China.

http:// minds.winconsin.edu/ bitsstream/ handle/ 1793/ 34571/ Zhu.\%20Lin .

Long, M. \& Porter, P. 1985. Group Work, Interlanguage Talk and Second Language Acquisition . TESOL Quarterly 19.

Long, M. H. 1989. Task, Group, and Task-Group Interaction. University of Hawaii Working Papers in English as a Second Language 8, 1-26

Mahmoud, M.M.A.W. (2018) The Effectiveness of Using the Cooperative Language Learning Approach to Enhance EFL Writing Skills among Saudi University Students. ISSN 17984769 Journal of Language Teaching and Research, Vol. 5, No. 3, pp. 616-625, May 2018 (C) 2018 ACADEMY PUBLISHER Manufactured in Finland. doi:10.4304/jltr.5.3.616-625

Mc Carthy, M. \& O'Keeffe, A. 2004. Research in the Teaching of Pronunciation. Annual Review of Applied Linguistics . 24, 26- 43

Muller, T. 2006. Researching the Influence of Target Language on Learner Task Performance. Proceedings from the Asian EFL Journal International Conference, $8(3)$.

Najamuddin, I. 2010. Developing The Students' Pronunciation Mastery Through Student -TeamAchievement-Division Type of Cooperative Learning Method. Makassar: UMM

Nguyen, H. and Terry, D. (2017) English Learning Strategies among EFL Learners: A Narrative Approach. IAFOR Journal of Language
Learning Volume 3 - Issue 1 Spring 2017. University of Tasmania, Australia and University of Melbourne, Australia.

Nunan, D. 2004. Task-Based Teaching. Cambridge: Cambridge University Press.

Olusegun, S. (2015) Constructivism Learning Theory: A Paradigm for Teaching and Learning. IOSR Journal of Research \& Method in Education (IOSRJRME) e-ISSN: 2320-7388,pISSN: 2320-737X Volume 5, Issue 6 Ver. I (Nov. - Dec. 2015), PP 66-70 www.iosrjournals.org

Oxford, R. 2006. Task-Based Language Teaching and Learning: An Overview. Asian EFL Journal.

Paulston, C. B. 1979. Communicative Competence and Language Teaching: Guide Line of Communicative Activities. RELC Journal Supplement.

Prabhu, N. S in International Journal of English Studies . 2004. The Cooperative Language Learning in language Teaching. University of Murcia.

Pollard, L. 2008. Lucy Pollard's Guide to Teaching English. E-book.

Richards, J. C. 2006. Communicative Language Teaching Today. Cambridge: Cambridge University Press.

Richards, J. C. and Schmidt, R. 2002. Longman Dictionary of Language Teaching and Applied Linguistics . London: Longman. Rivan, C. A. \& Webber, A.M. 1999. Improving Student Academy Achievement through Enhanced Communication Masterys .

Retrieved December 2008, from ERIC database.

Sae-ong, U. 2010. The Used of Taskbased Learning and Group Work 
Incorporating to Develop English

Pronunciation Mastery.Thailand:

Shrinakhrinwirot University.

Sarrica, T. (2018) Active Learning vs

Traditional Lecture. Which

Impacts Students More?

Sciencetific Article retrieved from https://www.hastac.org , sarricab > 2018/11/30.

Tarigan, G. H. Berbicara Sebagai Suatu Keterampilan Berbicara.

Bandung: Angkasa.

Ur, P. 1996. A Course in Language

Teaching . Cambridge:

Cambridge University Press.

Willis, J. 1996. A Framework for Task-

Based Learning. Longman: de Henseler Books. Vol. 18.

Zhang, Y. (2010). Cooperative Language Learning and Foreign Language Learning and Teaching. ISSN 1798-4769 Journal of Language Teaching and Research, Vol. 1, No. 1, pp. 81-83, January 2010 (C) 2010 ACADEMY PUBLISHER Manufactured in Finland. doi:10.4304/jltr.1.1.81-83

Zaenal. 2011. Improving Students' Pronunciation Preformance Through Team Game Tournament Method. Thesis. 
